\title{
TINDAK TUTUR DAN PRINSIP KERJASAMA DALAM KOMUNIKASI PADA PROSES PEMBELAJARAN BAHASA INGGRIS PROFESI PADA MAHASISWA MANAJEMEN AKOMODASI PERHOTELAN, STIPAR TRIATMA JAYA, BADUNG, BALI
}

\author{
Ni Putu Yunik Anggreni \\ Sekolah Tinggi Ilmu Pariwisata Triatma Jaya \\ yunikangreni73@gmail.com
}

\begin{abstract}
Abstrak
Penelitian ini mengkaji tindak tutur dan prinsip kerjasama dalam komunikasi pada proses pembelajaran Bahasa Inggris Housekeeping pada mahasiswa Manajemen Akomodasi Perhotelan di Sekolah Tinggi Pariwisata (STIPAR) Triatma Jaya. Penelitian ini bertujuan untuk (1) mendeskripsikan penerapan tindak tutur dalam menciptakan komunikasi yang efektif dalam proses pembelajaran Bahasa Inggris Profesi (2) Mendeskripsikan penerapan prinsip kerjasama dalam proses pembelajaran Bahasa Inggris Profesi. Jenis penelitian ini adalah penelitian deskriptif kualitatif. Metode penelitian yang digunakan dengan mengkaji Lesson Plan ( Teaching-Learning Activity Plan ) Bahasa Inggris Profesi yang digunakan pada Jenjang Diploma III, Program Studi Perhotelan, Konsentrasi Manajemen Akomodasi Perhotelan, semester 3 di STIPAR Triatma Jaya, Badung. Dari temuan tersebut ditunjukkan bahwa penerapan tindak tutur dalam proses pembelajaran Bahasa Inggris Profesi adalah berhubungan dengan konteks pembelajaran bahasa Inggris Profesi tersebut yaitu: (1) tujuan pembelajaran adalah mahasiswa dapat menerapkan ekspresi maupun ujaran-ujaran pada departemen tata graha ; (2) Terdapat tiga tahap aktivitas yang harus dilakukan yaitu (a) pre-activities, (b) whilst-activities, (c) postactivities; (3) metode pembelajaran yang digunakan ( a ) deductive method (b) working group and role play (c) discussion (d) reinforcement.; (4) metode evaluasi dengan Psychomotor/product Assessment.; (5) media yang digunakan media audia visual, media dalam metode sibernetik dan alat-alat yang digunakan oleh seorang telephone operator. Sedangkan penerapan prinsip kerjasama ditemukan penerapan (1) maksim kualitas (the maxim of quality) (2) maksim kuantitas (the maxim of quality): (3) maksim hubungan (the maxim of relevance), (4) maksim tata cara (the maxim of manner). Hasil analisis menunjukkan fungsi tindak tutur dan penerapan prinsip kerjasama pada pembelajaran Bahasa Inggris Profesi berperanan kompetitif dan menyenangkan.
\end{abstract}

Kata Kunci: Tindak tutur, Prinsip kerjasama, Bahasa Inggris Profesi

\section{PENDAHULUAN}

Salah satu tugas dosen dalam
proses membelajarkan mahasiswa. Proses ini tentu saja tidak terjadi begitu saja karena dalam proses pembelajaran terhubung beberapa elemen yang saling mempengaruhi: dosen, mahasiswa, media belajar dan situasi belajar. Keempat elemen ini "selalu berkomunikasi" dalam proses ini. Semakin komunikatif interaksi keempat elemen ini, akan semakin bermakna proses pembelajaran yang diharapkan.

Dalam konteks ini, dosen merupakan "tokoh kunci" dalam menghidupkan proses pembelajaran. Mahasiswa sebagai subjek pembelajaran mesti digerakkan, dibelajarkan dalam suasana yang kondusif. Ini akan 
berlangsung efektif jika dosen mampu melibatkan mahasiswa dalam berinteraksi dan berkomunikasi yang berkualitas dan bermakna.

Dosen akan mampu berkomunikasi efektif apabila memiliki kompetensi pragmatik yang baik. Pragmatik adalah ilmu yang mempelajari bagaimana menggunakan bahasa untuk berkomunikasi (Yule, 1996). Ilmu ini membekali para dosen untuk 'piawai' menyampaikan pesan yang bermakna bagi mahasiswa. Bermakna berarti tuturan dosen secara cepat dipahami mahasiswa sebagai modal mahasiswa untuk berfikir, karena mengajak mahasiswa berfikir merupakan inti dari proses pembelajaran. Dengan kata lain, berfikir akan memfokuskan mahasiswa untuk belajar sekaligus meningkatkan prestasi mahasiswa.

Dalam satu kasus, sebuah materi pembelajaran yang sangat sulit, akan mudah dipahami oleh mahasiswa bila dosen mampu membahasakan materi pembelajaran dengan baik dan terukur. Sebaliknya sebuah topik yang sangat mudah akan membingungkan mahasiswa apabila dosen membahasakan dengan berbelit belit, dan tidak komunikatif. Akibatnya, jangan heran dalam suatu kesempatan, mahasiswa sering mengklaim dan menilai dosen: "Kita sangat menikmati kuliahnya Bapak Agus ya "atau" Bosan belajar dengan Bapak Joni ". Pernyataan ini diasumsikan karena Pak Agus dapat menggunakan bahasa secara efektif sedangkan Bapak Joni belum mampu berkomunikasi secara efektif sehingga suasana kelas menjadi membosankan.

Terkait dengan fenomena tersebut maka, terdapat 7 hal yang diharapkan tercapai oleh seorang dosen dalam proses pembelajaran. Ketujuh hal tersebut adalah: (1) menjaga komunikasi dengan mahasiswa agar tetap harmonis; (2) membuat materi pembelajaran mudah dipahami; (3) membuat mahasiswa berfikir kritis; (4) membuat proses pembelajaran tidak monoton; (5) membuat mahasiswa tidak tidur selama proses pembelajaran; (6) membuat komunikasi antar mahasiswa berjalan komunikatif dan (7) memotivasi mahasiswa tetap belajar diluar kelas. Tujuan tersebut akan menjadi kenyataan apabila dosen menerapkan komponen pragmatik dalam proses pembelajaran yaitu: (1) tindak tutur; (2) prinsip kerjasama; (3) implikatur, dan (4) teori kesopanan (Thomas, 1995). Dan keempat komponen pragmatik tersebut saling berhubungan satu dengan lainnya guna mendukung dan menciptakan interaksi yang komunikatif dalam proses pembelajaran di kelas antara mahasiswa dan dosen. Merujuk pada pendapat Thomas tersebut dalam kajian ini akan kita paparkan 2 komponen pragmatik tersebut yaitu Teori Tindak Tutur dan Prinsip Kerjasama.

Bertitik tolak dari uraian diatas dan studi pustaka yang berkaitan dengan kajian ini maka yang akan dijadikan permasalahan dalam tulisan ini adalah:

(1) Bagaimanakah penerapan tindak tutur dalam menciptakan komunikasi yang efektif dalam proses pembelajaran Bahasa Inggris Profesi pada Mahasiswa Manajemen Akomodasi Perhotelan Diploma III Sekolah Tinggi Pariwisata Triatma Jaya, Badung Bali?

Bagaimanakah prinsip kerjasama dalam proses pembelajaran Bahasa Inggris Profesi pada Mahasiswa Manajemen Akomodasi Perhotelan Diploma III Sekolah Tinggi Pariwisata Triatma Jaya, Badung Bali?

Penelitian ini bertujuan untuk mengetahui bagaimana proses pembelajaran Bahasa Inggis Profesi yang baik dan efektif oleh dosen dari sudut pandang pragmatik khususnya teori tindak tutur dan Prinsip Kerja sama untuk 
mendapatkan tujuan akhir pembelajaran yaitu berhasilnya proses pembelajaran Bahasa Inggris Profesi.

\section{METODE PENELITIAN}

Metode Penelitian yang digunakan dalam kajian ini adalah bersifat deskriptif kualitatif, dengan mengkaji Lesson Plan ( Teaching-Learning Activity Plan ) dan RPPS Bahasa Inggris Profesi yang digunakan pada jenjang Diploma III, Program Studi Perhotelan, Konsentrasi Manajemen Akomodasi Perhotelan, semester 3 di STIPAR Triatma Jaya, Badung Bali.

Bahasa merupakan alat interaksi sosial atau alat komunikasi manusia. Dalam setiap komunikasi manusia saling menyampaikan informasi yang dapat berupa pikiran, gagasan, maksud, perasaan, maupun emosi secara langsung. Menurut faktanya, bahasa itu selalu muncul dalam bentuk tindakan atau tingkah tutur individual. Karena itu tiap telaah struktur bahasa harus dimulai dari pengkajian tindak tutur. Tindak tutur merupakan perwujudan konkret fungsi-fungsi bahasa, yang merupakan pijakan analisis pragmatik (Rahardi, 2005).

Searle (1976) mengklasifikasikan tindak tutur berdasarkan maksud penutur (dosen) ketika berbicara atau mengajar dalam kelas, dan yang menjadi acuan utama dosen dalam proses pembelajaran yaitu: (a) representatif yaitu memberitahukan mahasiswa mengenai sesuatu; (b) komisif, yaitu menyatakan bahwa dosen akan melakukan sesuatu; (c) direktif, yaitu untuk membuat penutur (dosen) melakukan sesuatu; (d) ekspresif, yaitu untuk mengekspresikan perasaan dan sikap mengenai suatu keadaan; (e) deklaratif, yaitu menggambarkan perubahan dalam suatu keadaan hubungan.
Terkait dengan teori tindak-tutur yang merupakan sebuah prinsip yang menyatakan bahwa bahasa yang digunakan oleh seorang dosen akan dapat dipahami dengan baik apabila dikaitkan dengan konteks dimana dan kapan terjadinya ungkapan tersebut. $\mathrm{Hal}$ ini mengandung makna bahwa dalam proses pembelajaran mahasiswa sebagai mitra tutur akan memahami apa yang dikomunikasikan oleh dosen kepada mahasiswa, apabila mahasiswa dan dosen berada dalam situasi konteks yang sama yaitu konteks pembelajaran, sama-sama berada dalam satu persepsi tentang: (1) tujuan pembelajaran; (2) apa yang dilakukan; (3) bagaimana melakukan; (4) apa dan bagaimana menilai; dan (5) media apa yang digunakan.

Austin (1962) menyebutkan bahwa pada dasarnya pada saat seseorang mengatakan sesuatu, dia juga melakukan sesuatu. Pernyataan tersebut kemudian mendasari lahirnya teori tindak tutur. Yule (1996) mendefinisikan tindak tutur sebagai tindakan yang dilakukan melalui ujaran. Jadi dapat disimpulkan bahwa tindak tutur merupakan suatu ujaran yang mengandung tindakan sebagai suatu kesatuan fungsional dalam komunikasi yang mempertimbangkan aspek situasi tutur.

Dosen dalam bertindak tutur berusaha mengungkapkan ide yang disampaikannya kepada mahasiswa dengan cara yang mudah dipahami untuk mencapai tujuan tertentu. Tujuan tersebut meliputi: (1) menyampaikan informasi, (2) meminta informasi, (3) memerintah, (4) menolak, (5) mengekspresikan perasaan, (6) mengangkat, (7) meminta perhatian, (8) menyampaikan permintaan, (9) meminta penegasan, (10) menunjukkan rasa solidaritas, dan (11) mengungkapkan terima kasih kepada mitra tuturnya. Untuk itu, penutur (dosen) harus mentaati aturan- 
aturan yang ada dalam sebuah tuturan. Aturan-aturan yang ada dalam sebuah tuturan oleh Grice (dalam Leech, 1991) disebut sebagai prinsip kerja sama dan prinsip sopan santun.Teori ini mengindikasikan bahwa apapun bahasa yang disampaikan dalam proses pembelajaran harus fungsional, harus memiliki fungsi dan bertujuan.

Prinsip kerjasama mengatur apa yang harus dilakukan oleh pesertanya agar percakapan yang dilakukan terdengar koheren. Menurut Grice (1991:309) kesearahan yang diakibatkan oleh kesamaan unsur dalam transaksi percakapan dapat dicapai dengan tiga hal yaitu penyampaian tujuan jangka pendek meskipun tujuan akhirnya berbeda ataupun bertentangan, menyatukan sumbangan partisipan sehingga penutur dan petutur saling mendukung hal yang dipercakapkan, mengusahakan agar penutur dan petutur memiliki pengertian bahwa transaksi berlangsung dengan satu pola tertentu yang cocok kecuali bila bermaksud mengakhiri percakapan. Grice mengemukakan bahwa di dalam rangka melaksanakan prinsip kerja sama setiap penutur harus mematuhi 4 maksim percakapan yaitu maksim kuantitas, maksim kualitas, maksim relevansi, dan maksim cara (Grice, 1975: 45-47).

Prinsip kerja sama (Cooperative Principle) dalam proses pembelajaran adalah komunikasi dosen yang lebih ideal menggunakan maksim Grice yaitu percakapan yang terjadi di dalam anggota masyarakat dalam hal ini terjadi di dalam kelas dilandasi oleh sebuah prinsip dasar, yaitu prinsip kerja sama (Yule, 1996: 3637). Kerja sama yang terjalin dalam komunikasi ini terwujud dalam empat macam maksim tuturan yaitu: (1) maksim kualitas (the maxim of quality): materi pembelajaran benar: (a) jangan mengatakan sesuatu yang diyakini salah: (b) jangan mengatakan sesuatu yang tidak didukung oleh bukti-bukti yang kuat ; (2) maksim kuantitas (the maxim of quality): (a) materi pembelajaran sesuai dengan kebutuhan mahasiswa; (b) materi pembelajaran tidak melebihi kebutuhan mahasiswa; (3) maksim hubungan (the maxim of relevance): materi pembelajaran relevan dengan topik pembicaraan; (4) maksim tata cara (the maxim of manner): materi pembelajaran itu mudah dimengerti, dalam arti: (a) hindari ketidakjelasan; (b) hindari ambiguitas (makna mendua); (c) harus singkat, dan (d) harus teratur ( Thomas 1995: 63-64).

Behavioris mengutamakan unsurunsur dan bagian kecil, bersifat mekanistis, menekankan peranan lingkungan, mementingkan pembentukan reaksi atau respon, menekankan pentingnya latihan, mementingkan mekanisme hasil belajar, mementingkan peranan kemampuan dan hasil belajar yang diperoleh adalah munculnya perilaku yang diinginkan.

Dosen yang menganut pandangan ini berpendapat bahwa tingkah laku mahasiswa merupakan reaksi terhadap lingkungan dan tingkah laku adalah hasil belajar.Manusia berbeda dengan makhluk lainnya karena kondisi psikologisnya yang membuat manusia maju. Perilaku kognetif, afektif, psikomotorik merupakan manifestasi karakteristik kehidupan manusia. Kondisi psikologis setiap individu berbeda karena perbedaan perkembangan, latar belakang sosial budaya dan faktor-faktor yang mempengaruhinya tergantung kepada konteks, peranan dan statusnya. Kondisi psikologis interaksi pendidikan, antara pendidik dengan terdidik harus sesuai, meskipun ada perbedaan antara jenjang dan lingkungan pendidikan berbeda. 


\section{PEMBAHASAN}

Pembelajaran Bahasa Inggris Profesi pada jenjang Diploma III, Program Studi Perhotelan, Konsentrasi Manajemen Akomodasi Perhotelan adalah proses pembelajaran bahasa Inggris yang lebih menekankan pada pembelajaran bahasa Inggris dari fungsi Bahasa Inggris tersebut (language use ). Metode pembelajaran yang diterapkan disini adalah Pendekatan Fungsional yaitu salah satu metode pembelajaran bahasa utama pada abad kedua puluh yang lebih menekankan penggunaan bahasa pada konteks tertentu. Hal ini juga dikenal sebagai Pengajaran Bahasa Fungsional. Program Studi Perhotelan, konsentrasi Manajemen Akomodasi Perhotelan adalah merupakan jenjang Diploma III yang mempelajari manajemen sebuah hotel, seluk beluk manajemen dari dua departemen yang terdapat di hotel, yaitu Departemen Kantor Depan, dan Departemen Tata Graham. Dan pada semester 2 materi perkuliahan difokuskan pada Departemen Tata Graha ( Housekeeping ).

Mata kuliah Bahasa Inggris Profesi (BIP), yaitu bahasa Inggris khusus yang disajikan dalam perkuliahan di STIPAR Triatma Jaya sesuai dengan bidang yang ditempuh dalam sebuah program studi, dalam hal ini yang digunakan dalam dunia perhotelan. Pada mahasiswa perhotelan, jenjang Diploma III, Manajemen Akomodasi Perhotelan, semester 2, BIP yang digunakan adalah BIP yang diterapkan pada Departemen Tata Graha. BIP juga merupakan salah satu mata kuliah yang dimuat dalam kurikulum Program Studi MAP III di STIPAR Triatma Jaya. Penyajian BIP juga dapat memotivasi mahasiswa untuk belajar lebih giat dan komprehensif terhadap bahasa Inggris, baik secara tulisan maupun lisan, mengingat begitu pentingnya peranan bahasa Inggris bagi mahasiswa MAP III di STIPAR Triatma Jaya.

Berbicara tentang Tindak Tutur yang diterapkan dalam pembelajaran BIP merujuk kepada penggunaan sebuah bahasa dalam proses pembelajaran yang dapat dipahami dengan baik apabila dikaitkan dengan konteks terjadinya ungkapan tersebut. Ini berarti, dalam proses pembelajaran mahasiswa sebagai mitra tutur akan memahami apa yang dikomunikasikan dosen apabila mahasiswa dan dosen berada dalam situasi konteks yang sama yaitu konteks pembelajaran, sama-sama satu persepsi tentang: (1) tujuan pembelajaran; (2) apa yang dilakukan; (3) bagaimana melakukan; (4) apa dan bagaimana menilai; (5) media apa yang digunakan.

Dalam kajian ini penulis akan mengkaji sebuah Teaching Learning Activity Plan dari Bahasa Inggris Profesi yang digunakan pada Mahasiswa Manajemen Akomodasi Perhotelan Semester 2 STIPAR Triatma Jaya. Berdasarkan data Lesson Plan (Teaching-Learning Activity Plan) yang diterapkan pada mahasiswa MAP Semester 2, tindak tutur yang dapat dikaji adalah sebagai berikut:

Bahasa Inggris profesi pada mahasiswa MAP, Diploma III semester 2 dimana pada semester tersebut mahasiswa harus menguasai kompetensi pada departemen Housekeeping (Tata Graha ), sehingga Bahasa Inggris Profesi yang juga harus dikuasi adalah Bahasa Inggris Tata Graha. Dalam hal ini tujuan pembelajaran adalah "The students are able to perform expressions in handling the guest in Hotel correctly" (mahasiswa dapat menggunakan dan menerapkan beberapa ekspresi maupun ujaran-ujaran yang digunakan dalam melayani tamu di hotel secara tepat dan efektif khususnya pada Departemen Tata Graha) 
Demi tercapainya tujuan pembelajaran Bahasa Inggris Profesi pada mahasiswa MAP Diploma III semester 3 maka yang harus dilakukan adalah dengan menerapkan "Teaching and Learning Activities" seperti yang bisa kita lihat pada tabel diatas Lesson Plan diatas. Terdapat tiga tahap aktivitas yang harus dilakukan yaitu ( 1 ) Pre-activities, 30 minutes, (2) Whilst-activities, 150 minutes, (3) Postactivities ( 20 minutes ). Dalam Teaching and Learning Activities tersebut dapat kita paparkan dimana semua aktivitas yang dilakukan sudah sesuai dengan kompetensi dasar dan tujuan pembelajaran Bahasa Inggris Profesi tersebut, contoh dalam Pre-activities terdapat Greeting. Terkait dengan aktivitas tersebut mahasiswa kita berikan warming up dengan memberikan greeting, bagaimana cara menyapa tamu pada pagi hari, siang hari, malam hari ataupun bagaimana menyapa tamu pada saat mereka melakukan aktivitas di Hotel sesuai dengan standar operasional prosedur (SOP) yang dimiliki oleh hotel.

Cara yang digunakan untuk melakukan dan menerapkan TeachingLearning Activity Plan tersebut dalam proses pembelajaran Bahasa Inggris Profesi pada mahasiswa MAP diploma III semester 3 adalah dengan menggunakan (1) Deductive Method (2) Working Group and Role Play (3) Discussion (4) Reinforcement.

Metode dan teknik di dalam pembelajaran tergantung pada tingkah laku yang tersirat dalam rumusan tujuan pembelajaran. Oleh karena itu metode dan teknik pembelajaran yang digunakan untuk tujuan yang menyangkut pengetahuan akan berbeda dengan metode dan teknik untuk tujuan keterampilan ataupun sikap. Contoh: (1.) tujuan-tujuan yang menyangkut aspek pengetahuan : mahasiswa dapat menjelaskan cara penggunaan kosakata atau kalimat yang diajarkan pada Bahasa Inggris Profesi (2) tujuan yang menyangkut aspek keterampilan: mahasiswa terampil menggunakan kosakata atau pola kalimat bahasa Inggris Profesi dengan benar, (3) tujuan yang menyangkut dengan sikap: mahasiswa mampu menerapkan kosakata, ujaran-ujaran yang tersususn dalam kalimat kalimat dengan efektif dan benar dengan sikap yang sopan dan ramah. Untuk tujuan yang pertama yaitu aspek pengetahuan dapat digunakan tanya jawab dan diskusi. Untuk tujuan kedua yaitu aspek keterampilan tentu saja perlu dipraktekkan bagaimana cara pemakaian kosakata atau pola kalimat bahasa Inggris baik secara lisan maupun dalam bentuk tulisan. Untuk tujuan ketiga, aspek sikap perlu memilih strategi yang lebih tepat, termasuk membiasakan pemakaian yang baik dan benar serta contoh dari dosen. (4) tujuan yang menyangkut penguatan ilmu pengetahuan yang didapatkan mahasiswa dalam hal ini dapat dilakukan dengan memberikan tugas terstruktur kepada mahasiswa dan membahasnya pada pertemuan berikutnya. Dan juga memberikan reward kepada mahasiswa yang sudah mengerjakan tugas dan sebaliknya memberikan punishment kepada mahasiswa yang belum mengerjakan tugas.

Cara menilai hasil dari proses pembelajaran Bahasa Inggris profesi pada mahasiswa MAP Diploma III semester 2 adalah dengan menggunakan Psychomotor / Product Assessment. Dalam proses assessment pada proses pembelajaran Bahasa Inggris Profesi ini dapat kita lakukan dengan memberikan 4 skills assessment yaitu reading assessment, writing assessment, listening assessment, dan speaking assessement. Proses assesment tersebut tidak hanya dilakukan pada akhir semester, namun 
juga bisa dilakukan pada tengah semester dan juga dilengkapi dengan pemberian tugas. (2) Affective Assessment ( Behavioral observation Sheet and Practice using telephone ), dalam hal ini dapat dipaparkan bahwa assessment yang dilakukan melalui konsep Filsafat pendidikan yaitu behaviourisme dimana dalam hal ini dilakukan methode penguatan (reinforcement). Behaviorisme ingin menganalisis bahwa perilaku yang tampak saja yang dapat diukur, dilukiskan dan diramalkan. Perilaku nyata dan terukur memiliki makna tersendiri, bukan sebagai perwujudan dari jiwa atau mental yang abstrak. Behavioris mempelajari rangsangan yang menimbulkan respon dalam bentuk perilaku dengan memberikan ganjaran dan hukuman yang mempertahankan adanya respon itu, dan mempelajari perubahan perilaku yang ditimbulkan karena adanya perubahan pola ganjaran dan hukuman. Bertolak dari konsep behaviorisme tersebut maka dengan memberikan praktik langsung misalnya dengan melakukan metode role play dan praktik menggunakan telephone secara langsung maka dapat kita amati perubahan sikap dan perilaku mahasiswa sebelum dan sesudah melakukan role play ataupun praktik tersebut. Kita mampu melakukan penilaian secara valid melalui proses tersebut diatas.

Media yang digunakan dalam proses pembelajaran Bahasa Inggris Profesi pada mahasiswa MAP Diploma III semester 2 yaitu (1) Media Audia Visual (2) Media dalam metode Sibernetik (3) Media/ alat-alat yang digunakan oleh seorang telephone operator. Sedangkan source atau sumber yang digunakan adalah English for Housekeeping, English for Room Division, dan Interchange.

Prinsip kerja sama dalam proses pembelajaran adalah bagaimana seorang dosen mampu berkomunikasi idealnya menggunakan maksim Grice yaitu percakapan yang terjadi di dalam anggota masyarakat, dalam hal ini terjadi di dalam kelas yang dilandasi oleh sebuah prinsip dasar, yaitu prinsip kerja sama (Yule 1996: 36-37). Kerja sama yang terjalin dalam komunikasi ini terwujud dalam empat macam maksim tuturan:

Maksim ini merujuk pada penerapan materi pembelajaran yang benar dan akurat : (a) jangan mengatakan sesuatu yang diyakini salah: (b) jangan mengatakan sesuatu yang tidak didukung oleh bukti-bukti yang kuat. Maksim hubungan (the maxim of relevance): usahakan materi pembelajaran relevan dengan topik pembicaraan Bahasa Inggris Profesi khususnya Bahasa Inggris Profesi Tata Graha diberikan kepada mahasiswa dimana sesuai dengan keahlian yang dipelajari dan ingin dikuasai dan mahasiswa harus mendapatkan mata kuliah bahasa Inggris yang materinya disesuaikan dengan program studi dan bidang studi yang mereka tempuh. Dalam kajian ini akan dibahas materi perkuliahan Bahasa Inggris berhubungan dengan topik pembicaraan sehingga sesuai dengan maksim hubungan dari Grice.

\section{PENUTUP}

Berdasarkan hasil penelitian yang telah diuraikan pada bab sebelumnya, simpulan dari hasil penelitian ini adalah sebagai berikut : tindak tutur dalam proses pembelajaran BIP adalah tindak tutur yang diterapkan dalam pembelajaran BIP di STIPAR Triatma Jaya sudah merujuk kepada penggunaan sebuah bahasa dalam proses pembelajaran yang dapat dipahami dengan baik apabila dikaitkan dengan konteks terjadinya ujaran tersebut. Hal ini terlihati dalam proses pembelajaran mahasiswa sebagai mitra tutur sudah memahami tentang apa yang dikomunikasikan oleh dosen dikarenakan 
mahasiswa dan dosen berada dalam situasi konteks yang sama yaitu konteks pembelajaran yang merujuk dalam satu persepsi tentang: (1) tujuan pembelajaran (2) apa yang dilakukan (3) bagaimana melakukan (4) apa dan bagaimana menilai (5) media yang digunakan.

Prinsip Kerjasama dalam Proses Pembelajaran BIP pada mahasiswa MAP diploma III semester 2 adalah : (a) Maksim Kualitas ( The maxim Of Quality), Merujuk kepada penerapan materi pembelajaran yang benar dan akurat, dalam hal ini materi pembelajaran BIP yang diberikan pada mahasiswa MAP III/2 sudah sesuai dengan unit kompetensi yang harus mereka kuasai pada semester tersebut yaitu pada departemen Tata Graha. (b) Maksim Kuantitas (The Maxim Of Quality), Maksim ini merujuk kepada materi pembelajaran sesuai dengan kebutuhan mahasiswa dan tidak melebihi kebutuhan mahasiswa. Materi yang digunakan pada pembelajaran BIP pada mahasiswa MAP Diploma III semester 2 sudah sesuai dengan lesson plan yang disiapkan. (c) Maksim Hubungan (The Maxim Of Relevance), Maksim ini merujuk pada materi pembelajaran relevan dengan topik pembicaraan. Pada pembelajaran BIP pada mahasswa MAP Diploma III Semester 2 materi pembelajaran sudah sesuai topik yang dipelajari. (d) Maksim Tata Cara (The maxim of Manner, Maksim ini merujuk kepada materi pembelajaran itu mudah dipahami dalam makna (1) menghindari ketidakjelasan menghindari ambiguitas (3) harus singkat (4) harus teratur ). Maksim tata cara sudah diterapkan dalam pembelajaran BIP pada mahasiswa MAP diploma III semester 2, hal ini terlihat dari materi yang digunakan dalam pembelajaran sudah singkat, teratur, mengandung makna yang jelas dan merujuk pada pengetahuan dan keterampilan di departemen Tata Graha.

\section{DAFTAR PUSTAKA}

Austin, John L. 1962. How to Do Things with Word (edisi kedua). Oxford: Oxfod University Press.

Grice, H.P. 1975. "Logic and Conversation", dalam Syntax and Semantics, Speech Act, 3. New York : Academic Press

Leech, Geoffrey. 1991. Principle of Pragmatics. London: Longman

Rahardi, K. 2005. Pragmatik: Kesantunan Imperatif Bahasa Indonesia. Jakarta: Erlangga

Searle, John R. 1976. Expression and Meaning: Studies in the Theory of Speech Acts. Cambridge: Cambridge Univercity Press.

Thomas. Jenny. 1995. Meaning in Interaction: an Introduction to Pragmatics. London/New York: Longman.

Yule, George. 1996. Pragmatics. Oxford. Oxford University Press. 